\title{
Medyanın Kör Noktası: Din
}

\author{
MUSTAFA RUHI ȘIRIN
}

\section{Din, Aile, Çocuk, Genç ve Medya}

Modern dünyada medyanın dine kör bakışı hangi zihniyet temeline dayanıyor? Bu sorunun cevabı önce iki düzlemde araştırılabilir: Modernliğin seküler zihniyet temelleri, bir. Yazılı, sesli ve görüntülü medyanın doğası, iki. Bu yazıda medyanın dine kör bakışını belirleyen bu iki düzlemi açıklamaya çalışırken, ortaya çıkacak muhtevayı, kısaca aile, çocuk ve genç odaklı eksende değerlendireceğiz.

Dünyayı kuşatan modernliğin zihniyet temelleri, sanayileşmenin sonuçları ile ilişkili olduğu kadar sanayileşme sonrasının da belirleyicisidir. Bütün modern iletişim araçları ise sanayileşme yanında modernleşme süreçleri ile de ilişkilidir.

Kapitalizmden tüketim kapitalizmine, endüstrileşmeden post-endüstriyel toplum ya da dijital toplum süreçleri yanında modernlik ve yüksek modernlik de seküler modernleşmenin zihniyet aşamalarıdır. Modernliğin üretim süreçlerini bizzat gerçekleştiren toplumlar ile üretilen modernliği tüketen toplumların modernlikle yüzleşmesi ne oranda yapılırsa yapılsın, yaşadığımız dünya tam anlamı ile modernliğin kuşattığı bir dünyadır.

Kendi modernliğini üretemediği gibi modernliğin üretimine katkısı olmayan, buna karşılık modernlik aşamalarının içine itilen toplumların üretilen modernliği kabulleri ise tektip modernleşmenin ömrünü uzatmaya yarıyor. Tektipleştirici modernleşme; kültürü meta'ya, (dolayısı ile gösteri toplumunun da en ünlü metası konumuna) yükseltirken, bu süreç, aynı zamanda dünyayı iki yüzyıldır yapay bir uygarlığa doğru itiyor (Debord, 1996, s. 104). Kendi medeniyet dairesinde modernliğini üretemeyen

- GÖRÜS-

Çocuk ve Medeniyet
MUSTAFA RUHi ȘiRiN, dunyaninenkucukcocugu@hotmail.com

Sair, Yazar, Cocuk Vakfı Kurucusu

doi: https://doi.org/10.47646/CMD.2021.265 
toplumların kültür şoku ile yüz yüze gelmelerinin temel nedeni de budur. Her medeniyet, tektipleştirici bu seküler yapay uygarlıkla ve kendi varoluş gerekçeleri ile yüzleşmedikçe, kendi değerler sistemini ve kendi modernliğini üretmedikçe değerlerin aşınması ve çözülme kaçınılmaz olarak sürecektir.

Dünyayı kuşatan tektipleştirici yapay uygarlığın insana ve dünyaya hükmeden bir zihniyet temeli vardır. Bilim, araçsallaşmış ve iktidar aygıtına dönüşmüş̧tür. Kültür, sentetik olduğu kadar üretilen ve satılan markalı metadır. Modern uygarlıkta her şey, metafizikten soyutlanmış ve aklileştirme süreçlerinde üretilir. Klasik medeniyetlerdeki insan ve toplum merkezli ahlaki geleneklerin yerine, birey ve haz kültürü egemendir. Toplum; kadın, çocuk, genç ve yaşlı gibi kategorilere ayrılmıştır. Din, klasik medeniyet alanında belirleyici iken, dinî kozmos yapay uygarlıktan kovulmuştur. Modern 'uygarlık'ta dinin yerine akıl, iyiliğe karşılık ise fayda ikame edilmiştir. Modern 'uygarlık', kendini dinden soyutlayarak ve seküler bir alt yapı üzerine kurulduğu için din dışlanmıştır.

Modern seküler uygarlıkta özellikle görsel medya, taşıyıcı ve yaygınlaştırıcı rolleri olan en etkili enstrümanlardır. Bu araçlar, bir yandan bilgi ve değer aktarırken, öte yandan da değer aşındırıcı işlevi yerine getirmektedirler. Zihniyet çatışmasına yol açan bu iletişim sürecine itirazlar da yapılmaktadır: "Dinlerin, inanç sistemlerinin binlerce yıl içinde insanlığa kazandırdığı kıymet hükümleri ve değer yargıları kitle haberleşme araçları tarafından nispeten kısa zamanda aşındırılmakta ve yerlerine yeni ölçüler konabilmektedir. İletişim araçları fikir ve inanç yayıcı; belli açılardan yorumlarla fikir ve inançlara ait yapı oluşturucu; sürekli tekrarlarla düşünceyi devreden çıkararak otomatik hüküm verdirici; günlük hadiselerden inanç kesinliğinde hükümler üretici tesirler uyandırmaktadır. Kitle yayın vasıtaları, kütlevî fanteziler, hayaller ve imajlar üretmektedir. İnsanların akliliğini dumura uğratarak günlük, anlık arzuları ön plana çıkarmaktadır." (Doğan, 1996, s.1313). Sentetik-yapay uygarlığın yaygınlaşmasında, iletişim araçlarının etkili biçimde kullanılmaları belirleyici olmakta mıdır? Hiç kuşku yok ki iletişim araçlarının mesajları, bu mesajları kabule hazır toplumlarda daha etkili olmaktadır. Bu görüşü en azından merkez medya durumundaki televizyon için ileri sürmek mümkündür.

İletişim araçlarının etkilerini toplumların "değer üretimi” ile "değişme dinamikleri”ni ilişkilendirmeden öğrenemeyiz. Her toplumda kültürel değerleri aktarma görevini önce aile üstlenir. Ailenin değer üretiminde ve aktarımında etkili olduğu toplumlarda medyanın etkileme gücünün az 
olduğunu biliyoruz. Buna karşılık aile, değer üretim ve aktarımında etkisiz durumda ise medyanın bu boşluğu doldurması kaçınılmaz olmaktadır. $\mathrm{Bu}$ durumda aile, değer üretici konumundan medyanın hazır değer alıcı duruma açık hâle gelmektedir. Değer üretiminde etkisizleşen ailenin yaygın olduğu toplumlarda kültürel yoğunluğun azalması ise kaçınılmaz bir sonuçtur.

Merkez medya olan televizyonun hedeflediği ana birim ailedir. Bütün dünyada televizyon yayınları aile odaklı olarak planlanır ve gerçekleştirilir. Televizyon, ailenin bireylerine göre kendini tanımlarken, “enformatik, kültürel ve değerler sistemine ilişkin etkiler, televizyonun, aile ortamında olduğu kadar bireysel ve toplumsal düzeyde de kültürü oluşturan en önemli sosyalleştirme kurumlarından biri olduğunu ortaya koymaktadır." (BatmazAksoy, 1995, s.3). Bu nedenle, iletişim araçları içinde televizyon, kültürel kuruma dönüşmüş ilk medyadır.

Medya okuryazarlığı düzeyinin düşük olduğu ailelerde, medyanın kültürel etkisi daha geniş boyutlu olmaktadır. Kültürel göstergeleri yüksek olan ailelerde, televizyonun değer aktarımında etkisi ise daha sınırlıdır. Bu sonuçtan hareketle, medyanın etkilerini yalnızca denetimle önlemek mümkün olamaz. Çünkü medyanın kültürel etkileri denetime rağmen dolaylı olarak da mümkün olabilmektedir. Kültürel göstergeleri ve eleştirel medya okuryazarlığı çıtası yüksek ailelerde, medya etkisinin hiç olmadığı ise iletişimin doğasına aykırıdır. Medya herkesi etkiler; ancak, çocuk ve genç üzerindeki medya etkisi hem daha kolay hem de çok yönlüdür.

Modern uygarlıkta dine en mesafeli duran enstrümanlar iletişim araçlarıdır. Dinî içerikli programlar muayyen zamanlarda özellikle televizyonun doğasını dönüştürse de televizyonu kodlayan odak buna uzun süre izin vermez. Böylece din, televizyon dili ile bir kitle kültürüne dönüşerek yayın akışı içinde hızla kaybolur. Neil Postman, dinî içerikli programların televizyon ekranında yer almasına rağmen, televizyonun seküler bir medya olmasını şöyle açıklıyor: Televizyon ekranı, sekülerizm psikolojisi yaratmak gibi doğal bir yönelimi temsil ediyor. Bu güçlü araç, bellekleri dinî olmayan olaylarla doldurmaktadır. Dinî göstergelere bir çerçeve hazırlayacak şekilde yeniden düzenlenmesi ise çok zordur. Seyirci bir düğmeye basarak farklı bir dünyevi görüntüye (bir hokey maçı, bir reklam veya bir çizgi film) geçebileceğinin her zaman farkındadır (Postman, 1994, s.132). Sonuç olarak, Postman, "ekranın asıl mesajı aralıksız bir eğlence vaadi olmasıdır." görüşünde israr ediyor.

Çocuk ve Medeniyet 2021/2
Televizyonun kuşatıcı ve etkin olduğu bu eğlence örgüsü üzerinde durmak gerekiyor: Televizyon ekranının hem tarihi hem de şimdiye kadar sunmuş olduğu imkânlar, televizyon açıkken iç gözleme kaymanın veya manevi 
aşkınlığın olabileceği fikrini temelinden çürütür. Çünkü televizyon ekranı, sizden, görüntülerin daima eğlenmeniz ve haz almanız düşünülerek hazırlanmış olduğunu unutmamanızı ister.

Yoğun medya tüketicisi olan toplumlarda, dinin de "eğlence gibi" sunulduğu ise ortak kabullerden biridir. Medya fetişizminin yaşandığı ortamlarda, dinin, derinlikli ve kutsal bir insanî etkinlik durumuna sokan bütün özellikleri silinmiştir. Dinin ayıklandığı medya süreçlerinde, ne bir ritüel ne bir dogma ne bir gelenek ne bir teoloji ve her şey bir yana ne de ruhsal bir aşkınlık duygusu söz konusudur. Neil Postman'ın da belirttiği gibi, televizyonda gösterilen şeyler, özleri korunmuş olsun olmasın, oldukları durumdan başka bir şeye dönüştürülmüştür. Televizyon vaizleri bu konu üzerinde düşünmemiş olamazlar. Buna rağmen bir kilisede veya çadırda yüz yüze kurulan ilişkilerin, televizyonda anlamından hiçbir şey kaybetmeden ve duyarlılığın azalmadan sürdürülebileceği yanılgısından kurtulamamışlardır. Aslında bu durum, bütün dinlerin vaizleri için de geçerlidir.

Televizyon ekranı seküler bir aynadır. Elektronik vaizlere rağmen televizyonun seküler yapısı değişmiyor. Kısa süreli dönüşümleri de sabun köpüğü gibi uçup gidiyor. Zaten elektronik vaizler dışında televizyonda din merkezli programlara ya çok az yer veriliyor ya da hiç yer verilmiyor. Çocuklar ve gençler, televizyonlardaki programlardan daha çok "şelaleleri veya tele drama türü yapımlarda başrol oynayan sinema, tiyatro veya şarkıcı yıldızları" hatırlıyorlar. Reklamları veya markaları. Kiliseyi, nikâh törenlerini ve ayinleri. Bugün bütün dünya çocuklarına ve gençlerine daha çok tanıtılan sembol ve ritüeller ise İncil ve Tevrat kaynaklıdır. Sınırları aşan çocuk ve gençlik yayınlarının hâkim karakteri de benzer bir içeriktedir.

Televizyon kanallarında çocuğa ait, çocuğa dair, çocuğa göre, çocuklar için hazırlanmış dinî muhtevalı programlara nadiren yer verilir. Din, büyük çoğunlukla yetişkinlere anlatıldığı biçimde çocuğa anlatılır. Daha doğrusu din mabetlere bırakılmıştır ve mabetlerde ise çocuk yoktur. Mabetleri çocuksuz kalan bir dünyada görsel medya mabetlerin bıraktığı boşluğu doldurmakla görevlendirilmiş gibidir. Televizyona ve yeni medyalara bu işlevini seküler düşünce ortamı hazırlamıştır. Aydınlanma Çağı, dünyevi cennet vadediyordu. Bu dünyevi cennet rüyasını ise televizyon ve medya gerçekleştirmiştir. Modern uygarlıkta bunun anlamı şudur: Görsel medya aynı zamanda modern zamanların dijital mabetidir.

Seküler zihniyetle beslenen medya, dinin üzerini çok yönlü illüzyonları ile örterken, çocuğumuzla aynı gemide olduğumuzu çoğu zaman unutuyoruz. 2021/2 Bu yanılgının en temel nedeni şudur: Televizyonda size ve çocuğunuza ait ayrı ayrı alanlar yoktur. Her şey herkes içindir. Çocuk, yetişkinler dünyası 
içinde âdeta kaybolmuş gibidir. Herkes aynı dizileri seyreder, aynı çizgi filmlere müpteladır, aynı paparazzileri takip eder, daha az sıklıkta da olsa aynı vaizi dinler. Yani artık merkez medya televizyonda, çocuğunuza ait ayrı bir programdan söz etmemiz zordur. Televizyon dışı medya dünyası ve özellikle çocuk medyasının içeriği de benzer anlayışa göre yapılandırıldığı için çocuk maneviyatı, genelde çocuk ve yetişkin medyasından kovulmuş gibidir. Arada bazı uzman açıklamalarını duyar gibi olursunuz. Büyüme ve gelişme çağı çocuklarının dil, duygu ve düşünce gelişiminden söz eden konuşmacıların dinin yerine psikolojiyi ikame ettiğini ise çoğu ebeveyn fark edemez. (Şirin, 1999, s.128-129).

Merkez medyanın dinî muhtevaya kapalı oluşu, modern zihniyetten kaynaklanmaktadır. Neil Postman, buradaki asıl tehlikeyi ise dinin televizyon programlarının muhtevasına girmesinde değil, televizyon programlarının dinin muhtevasına girmesi olasılığı ile açıklamaktadır. Şu anda dünyada hâkim olan bu yöndeki yaklaşım dönüştürülmedikçe, iletişim araçları ve özelde ise merkez medya olan televizyon ile din arasındaki ilişkinin düzelmesi imkânsızdır.

Türkiye'de medya-din ilişkisinin üç düzlemde problemli olduğu söylenebilir: Modernliğin yansıtıcısı olarak medyaya hâkim olan seküler zihniyetin egemenliği, bir. Medyanın dine yer veriş biçimleri, iki. Dinî kodlara göre dinin medyada sunuluşu, üç. Buradaki her üç başlığın cevaplandırılması, Türkiye'de medya türlerinin kullanılmaya başladığı tarihten bu yana incelenmesi ile mümkün olabilir. Bu ise bu yazının sınırlarını aşmaktadır. Bizim yapmak istediğimiz değerlendirme ise yukarıda belirttiğimiz üç ayrı düzlemin bugüne yansıyan sonuçlarını tespite yönelik olacaktır.

Yazılı, özellikle de sesli ve görüntülü medya modernleşme döneminin ürünleridir. Türkiye'de bu medya türleri başlangıcından günümüze kadar modernliğin kültür ve eğitim formları ve kodlarına göre kullanılmışlardır. Geleneksel iletişim ortamlarının etkinliği, modernleşme döneminden itibaren zayıflama eğilimi içine girdikçe, yeni medya türleri toplumun iletişim merkezleri durumuna gelmiş oldu. Medeniyet ve kültür kodlarına göre sürdürülen doğal haberleşme ortamı ve geleneğine müdahale edilmesi sonucu, kadim haberleşme geleneğinin yerine modern iletişim araçlarının ikame edilmesi gecikmedi. Bugün artık gazete, dergi, kitap, radyo, sinema ve televizyon yanında ses ve görüntü aktarımına yönelen dijital yeni medya, yaşama biçiminin merkezî bir konuma yükselmiştir.

Henüz medya türlerine göre göstergeleri bilinmeyen bir toplumda, dinmedya ilişkilerini çocuk ve genç merkezli değerlendirmenin zorlukları ortadadır. Ancak, Türkiye'de medya, seküler modernlikten yana olduğu 
ortak kabulü bile medyaya hâkim olan zihniyetin tespiti için yeterlidir. Medya, yapay modern uygarlıkla ilişkilerini sürdürüp onun kodlarını kullandıkça, kaçınılmaz olarak dünyaya tek bir uygarlık duygusunu pompalıyor. Bu yönü ile modern uygarlık, dini dışlayıcı tutumu yüzünden, medeniyetleri tektipleştirici etkinliğini bugün de sürdürmektedir.

Türkiye'de dinin medyada yer alış biçimi de farklı değildir. Dinî muhtevalı yayınlar, genelde haftalık periyodlarda elekronik vaiz saatleri -konuşan kafalar-, film, dizi ve programların içeriğine dinin dâhil edilmesi ve özelde televizyonlarda dinin içeriğine müdahale edilen programlar vb. biçiminde gerçekleşmektedir. Yalnızca dinî içerikli radyo ve televizyon yayınları ise başlı başına bir inceleme konusudur. En yaygın olan dinî programlar, haftalık periyodlarda yayımlanan televizyon programları olmakla birlikte, bu programlar çocuk dili'ne uygun değildir. Bu dinî programlar büyük ölçüde yetişkinin din algısına göre hazırlanır. Çocuğa göre ve çocuk bakışı dikkate alınarak hazırlanan dinî çocuk yayınları, televizyonun günlük yayın akışında yer almadığı gibi, çocuğa yönelik kuşak programların içinde dinî muhtevaya dolaylı olarak yer verilir. Merkez medya televizyon yönetimleri tarafindan dinin hatırlandığı zaman dilimleri, Ramazan dönemidir. Bu ay boyunca çocuklar yine unutulur. Bu programlarda çocuk, bayramda hatırlanan nostaljik bir yaklaşımdan öte bir anlam içermez. Her alanda olduğu gibi çocuk, dinî alanda da nesne gibi yansır görsel medyalara. Bu ise medyaya yansıyan dinî içerikli yayınların en temel çelişkisi olduğu gibi, din alanında modern çocuk paradigması sarmalının din boyutudur.

Modern çocuk paradigması, çocuğu ayrı bir kategori olarak tanımlar. Çocuğun büyüme ve gelişmesinden, çocuğun medeni, sosyal, kültürel ve ekonomik haklarından yetişkini sorumlu tutar. En temel haklardan biri olan "çocuğun düşünce, vicdan ve din özgürlüğü hakkını" tanır. Trajik ama gerçek; medya çocuğun inanma hakkına, din kozasının örülmesine ve çocuk maneviyatına hemen hemen hiç yer vermez. Buna karşılık küçük yaştaki çocuk dindarlığına eleştirel yaklaşır. -Bu durum en azından bizde böyledir. -

Çocuk ve din ilişkisinin yansıtıldığı diziler, filmler ve basılı yayınların tamamına yakını ise dış yapım çocuk ve genç kültürünün örnekleridir. Pembe diziler dâhil, kargo çocuk kültürü ile gelen yayınlarda Hıristiyanlık ve Museviliğin yer almasında sakınca görülmez. Buna karşılık Türkiye'de çocuğa ve gence yönelik dinî yayınların bir bölümü İslam dini dışındaki dinlerin misyonerlik amaçlı yayınlarıdır. İslam dini ile çocuğun iletişim ortamındaki ilişkisi yerli film ve dizilere dinin yansıması ile sınırlıdır. Kaldı ki yerli film ve dizilere yansıyan din, çoğunlukla kara mizah bir yansıma biçiminde olmaktadır. 
Televizyonun çocuk dindarlığını yansıtma biçimi ile gazete ve dergilerde çocuk ve din temalarının yer alış biçimleri de birbirine paraleldir. Ülkemizde basılı çocuk yayınları arasında dinî çocuk kitapları en yaygın tür olmasına rağmen, bu yayınlar, çocuk gerçekliği, pedagojik, görsel ve estetik kabul ölçütleri bakımından çıtaları çok düşük yayınlardır. Basılı yayınlar dinî muhteva yönünden en uygun form olmasına rağmen, bu yayınlarda yer alan din dili de çocuk özne'ye uygun, çocuk bakışı'na göre bir din dili değildir. Buna karşılık 1970 sonrası basılı dinî çocuk yayınlarında artışın olması, kimilerine göre modernleşmenin uğradığı başarısızlığa tepkinin sonuçlarından biridir (Tapper, 1993, s. 237-239). Bu görüş, oryantalist bir ön kabule dayanmasına rağmen doğrudur. 'Bir popüler edebiyat biçimi olan resimli çocuk kitapları aracılığıyla evlerdeki din eğitimine bakarak', 'ideal tip' yetiştirmek, modernleşmenin vitrini olan medyaların dine kayıtsız kalmalarına gösterilen tepki ile açıklanabilir. Dinî çocuk ve gençlik yayınları sürecinin Türkiye'de televizyon yayıncılığına paralel olarak ortaya çıkması ise çocukların din ile ilişkilerinin kurulmasına yönelik bir evredir ve modernleşmeye yönelik tepkinin sonuçlarından biridir.

Medya-din ilişkisinde hiç şüphesiz en önemli birim ailedir. Türkiye'de modernleşme sürecinde ailenin değer üretici konumundan değer alıcı durumuna geldiği ise sosyal bilim çevrelerinin son üç Aile Şûrası'na yansıttığ1 eleştirel ortak görüşlerden biri olmuştur. Değer üretemeyen ailenin, mevcut değerleri tüketmesi ve değerler konusunda ortaya çıan boşluğu, medya aracılığı ile hazır değer ithali ile doldurmaya yönelmesi, Türkiye'de ailenin krizine işaret etmesi bakımından önemlidir. Çünkü toplumu kuşatan iletişim süreçleri iletişim araçlarının sınırlarını ve muhtevasını kendi "rasyonel"i doğrultusunda yeniden biçimlendirmekte, daha doğru bir ifade ile bu çerçeveyi kendi "rasyonel”i doğrultusunda odaksızlaştırmaktadır (Avcı, 1990, s. 102).

Aile yapısının kültürel değerleri aktarma işlevinin sınırlanmış olması, aile tarafından dinî değerlerin aktarılmasını da sınırlandırmaktadır. Dinî değer öğretimini ve eğitimini medya alanına terketmek ise en trajik toplumsal paradokslardan biridir. Çünkü medya, dini aklileştirerek vermekte ve dinî kozmosu yok etmektedir. Daha açık bir ifade ile belirtmek gerekirse, modern medya dinin muhtevasına müdahale ettiği gibi modern medya türlerinin doğası da dinî kozmosa uygun değildir. Bu nedenle, Batı merkezli seküler kültür ve bilgi kodlarının kullanıldığı modernleşme dönemi bütün 2021/2 modern dünya insanının temel uygarlık açmazıdır.

Sonuç olarak; modernliğin yansıtıcısı olarak medyaya egemen olan zihniyet ve medyanın dine yer veriş biçimleri yanında, dinî kodlara göre dinin 
medyada sunuluşu ve yer alma biçimi, dinin medya vaizlerinin inhisarına girmesi tehlikesi ile birlikte düşünülmesi gereken bir durumdur. Dinî kozmos alanına müdahale edici hiçbir medya, dinin doğasını yansıtamaz. Çünkü dinin doğasını yansıtmak dijital dadıların yapacağı bir iş değildir.

Din ile medya arasındaki bu çelişki nasıl önlenebilir? Medyanın sahih din geleneğine ve din dili'ne sadık kalarak dine kör bakışı kısmen dönüşebilir. Bu ise medya dili'nin egemenliği ile değil, din dili'nin medyanın dili'ni dönüştürmesi ile mümkün olabilir.

Türkiye örneği dikkate alınarak, çocuk ve genç özneye yönelik dinî yayınların durum tespitinde ise şu sonuçlara ulaşabiliriz: Aile, çocuk ve gence yönelik dinî yayınların sesli, görüntülü basılı medyada yer alış biçimine dinî muhteva değil, modern zihniyet ve medya türünün doğası hâkimdir. Türkiye'de çocuk ve genç hedef kitlesi için tasarlanan sesli, görüntülü ve basılı dinî yayınların dil ve anlatım dizgesi, çocuk ve genç özneye göre değil yetişkin kimliğine göredir. Çocuk ve gencin din ile ilişkisinde, dinin çocuğun ve gencin psikolojik ve pedagojik açılımına uygun, dinin temel değerlerini yansıtan nitelikli, bütünlüklü ve estetik açılıma sahip çok yönlü dinî yayın programı, aile odaklı, çocuk ve genç merkezli bir muhtevada olmalıdır.

\section{Din, Çocuk ve İletişim Araçları}

Dinin, aklîleştirilerek veya görsellikle somutlaştırılarak sunulması, dünyevi bir alana indirgenmesi tehlikesini doğurur. Pozitivist yaklaşımla aklın mutlaklaştırılması ise seküler zihniyetin en tipik örneğini oluşturur. $\mathrm{Bu}$ yaklaşım sonucu, aklın kavrayamayacağı soyut ve sembolik değerler (metafizik boyut) ayıklanarak din ete kemiğe büründürülür.

Dinî, akıl ile sınırlamanın yanında, çocuk gerçekliğine göre dinî çocuğa anlatmaya yönelik bir çocuk din dili'nin olmayışı çocuk ve din sarmalının başat sorunudur.

Yaşadığımız dünyada anlatılan din, yetişkinleri hedef kitle seçen bir yaklaşımın sonucudur. Çocuğun din dili’ne yönelmesi için özellikle çocuk medyasında çocuk maneviyatının kapıları hemen hemen hiç açılmaz.

Küresel ölçekli iletişim araçlarında dinin sunuluş biçimi ise İncil ve Tevrat merkezlidir. Dine dair anlatımda bu iki kutsal kitabın belirleyici rol oynaması modern enformasyonun oluşturduğu bir sonuç olarak kabul edilebilir. Sinemadan televizyona kadar uzanan görsel medyada bu iki kitabın sembolleri ve yorumları egemen bir dile dönüştürülüyor. Üretilen 
mesajlar ise sınır tanımadan yaygın bir kargo kültür ağı oluşturuyor. Dünya çocukları bu yaygın din kültürünün etki alanı içinde büyüyorlar. Çünkü İslam'ın ve son ilahi kitap Kur'ân'ın, çağın insanı ile çok sınırlı iyi örneklerle gerçekleşebiliyor. Yetişkinler için de çocuklar için de iyi örnekler aynıdır. Hatta çocuklar açısından iyi örnekler daha da azdır.

Çocuğun dinî dünyasını "çocuk dini” kavramını merkeze alarak anlamak mümkündür. "Çocuk dini” yeni bir din değildir. Yetişkin ile çocuk arasındaki dünyaya bakış, algılama ve bilinç farklarını belirtmek amacı ile bu kavramı kullanabiliriz.

"Çocuk dini" kavramı, çocuğun, yetişkinlerin oluşturduğu muhtevayı olduğu gibi alamayacağı ve anlayamayacağı esasına dayanıyor. Çocukluğunu yaşayanlar ve hâlâ çocukluğunu hatırlayabilenler iyi bilirler; çocuk, inancını, dinî duygu ve düşünce dünyasını kendisi inşa eder. Dış dünyadan aldıklarını "istidat ve kabiliyetleri” ile içselleştirdikçe kendine özgü dinî inancı geliştirir.

Çocuğun oluşturduğu dinî inancın, yetişkininkinden farkı, çocuk ile yetişkin arasındaki duygu, düşünce ve hayal farkı kadardır. "Çocuk dinî”ne ağırlıklı olarak yetişkinler yön verir. Çocuğun ileride yaşayacağı dinî hayatın temeli, çocuklukta atılır. Cevabını aradı̆̆ı her şeyi kavrayıncaya kadar soru sorar çocuk; ruhî ihtiyacını ve arayışını sürdürür. Bu sorular mahiyet bakımından yetişkinlerin sorularına benzese de biçem/üslup bakımından birbirine benzemezler. Çocuk, yaşamak ve hissetmek istediği dinin, ruhunun derinliklerine kök salmasına aşırı isteklidir. Zaten çocuk demek inanma ve coşku demektir. Çocuk dindarlığının temeli ise Allah'a inanma ve bağlanma ile başlar.

Çocuk dindarlığının oluşumuna çocuğun "samimi, sıcak ve duygusal” doğası yön verir. "Yetişkinler dini akıl, çocuklar ise duyguları ile taşır" sözü, çocuğun safiyetini doğruluyor.

Kerim Yavuz, "çocuğun dini, yetişkinlerin dinine benzer ama bu onların dininin aynısı demek değildir." görüşünü savunur. Çocuk, dini, kendisinden hiçbir şey katmadan yanlızca yetişkinlerin kendisine aktarmış olduğu gibi kabul etmez. Çocuğa öğretilen din, onun içinde inanca dönüşürken ana-baba dindarlığı olmaktan çıkar ve çocuğun inancı olmaya başlar. "Öyle ise çocuk dini, yalnızca yetişkinlerin dinine bağlanamaz. Çünkü çocukluk, dindarlığı inanma yönünden değil, yetişkinlerin dininden inanç keyfiyeti bakımından

Çocuk ve Medeniyet 2021/2 farklıdır. Onların tesiri, çocuğu olumlu yönde etkilediği gibi olumsuz yönde de etkileyebilir. Yetişkin ona dinini öğretebileceği gibi çocuğun dininin yıkılmasına da sebep olabilir." (Yavuz, 1994, s. 190). Kerim Yavuz, bu 
bilgilere dayanarak şu sonuca ulaşılıyor: Büyüklerin dini, nasıl çocukluk döneminin dini üzerine oturuyorsa ve geçmişin bir uzantısı ise "çocuk dini”ni de geçmişin desteğini almadan anlamaya çalışmak doğru olmaz.

Madalyonun iki yüzünü de doğru okumalıyız: Bir yüzü çocuk diğer yüzü yetişkin olan bir madalyon. Dini, çocuğa ve yetişkine göre anlatmak yine yetişkinlerin görevidir. İletişim araçlarından önce dinin çocuk dili ile çocuğa ve yetişkine nasıl anlatılacağı ise problemin asıl kaynağıdır.

\section{Din, Elektronik Vaiz ve Televizyon}

Tarih boyunca sayısız iletişim aracı geliştirildi. En güçlü, en etkili, cazip ve en yaygın kullanımı olan ilk medya televizyon oldu. Güçlü tarafı, "kafalarımıza soyutlamalar değil, kalplerimize kişilikler sokmasındadır." Etkili oluşu, ondan bir türlü kurtulamayışımızdan, cazip oluşu ise dinamik görsel imgelerin dili ile konuşmasından kaynaklanıyor.

Televizyonun güçlü, etkili ve cazip oluşunu daha üst bir anlama dönüştüren en evrensel tema ise din'dir. İnsanoğlunun ortak duyarlığı olan dinî değeri yansıtması bu araca ilgiyi artırabilir. Din teması televizyon veya diğer görsel medyalara karşı olan güvensizliği de ortadan kaldırabilir.

Neil Postman, içinde yaşadığı Amerika toplumunda televizyonda dinin bir eğlence gibi sunulduğu görüşünde: Dini, derinlikli ve kutsal bir insanî etkinlik durumuna sokan bütün özellikleri silinmiştir. Ne bir ritüel, ne bir dogma, ne bir gelenek, ne bir teoloji ve her şey bir yana ne de ruhsal bir aşkınlık duygusu söz konusudur. Başlıca rolï "vaizin yerine getirdiği, Tanrı'nın 'ikinci muz'olarak sunulduğu” programlardır. Bu ise elektronik vaizlerin eksiklerinden ziyade, televizyonun içerik yönelimi ile ilintilidir. Televizyon vaizlerinin zayıflıkları kendilerinden daha çok faaliyet gösterdikleri aracın (medium) zayıflıklarında aranmalıdır. Çünkü her şey televizyonda gösterilmez. Postman, daha açık bir ifadeye başvurma ihtiyacı duyar: Televizyonda gösterilen şeyler, özleri korunmuş olsun olmasın, oldukları durumdan başka bir şeye çevrilmiştir. Televizyon vaizleri bu konu üzerinde hiç düşünmemiştir. Bir kilisede veya çadırda yüz yüze kurulan ilişkilerin, televizyonda anlamından hiçbir şey kaybetmeden ve duyarlığın azalmadan sürdürülebileceği yanılgısından kurtulamamışlardır. Bu, bütün dinlerin vaizleri için de geçerlidir.

Gösteri toplumlarında din merkezli programlar bol bol alkışla doludur. Bu programlarda bolluk kutsanır. Postman, fundamentalist programların 
psikolojisi yaratmak gibi doğal bir yönelimi temsil ediyor. Bu güçlü araç, bellekleri dinî olmayan olaylarla doldurmaktadır. Dinî göstergelere bir çerçeve hazırlayacak şekilde yeniden düzenlenmesi çok zordur. Seyirci bir düğmeye basarak farklı bir dünyevi görüntüye (bir hokey maçı, bir reklam veya bir çizgi film) geçebileceğinin her zaman farkındadır. (Postman, 1995, s. 132).

Televizyondan yayınlanan din merkezli programlardan hemen önce veya sonra gene reklamlar, popüler programların tanıtım çekimleri ve çeşitli dünyevi görüntülerle söylemlere yer verilmektedir. Postman, vurgusunu ihmal etmiyor: Ekranın asıl mesajı aralıksız bir eğlence vaadi olmaktadır. Televizyonun zengin metaforlarından olan eğlence örgüsünün açık anlamına burada ihtiyaç duyuyoruz: Televizyon ekranının hem tarihî hem de şimdiye kadar sunmuş olduğu imkânlar, televizyon açıkken iç gözleme kaymanın veya manevi aşkınlığın olabileceği fikrini temelinden çürütür. Televizyon ekranı sizden, görüntülerinin daima eğlenmeniz ve haz almanız düşünülerek hazırlanmış olduğunu unutmamanızı ister.

Din, televizyon dili ile bir kitle kültürüne dönüşerek televizyon programlarının içinde eriyerek kayboluyor. Alabildiğine hormonlu televizyon programları dinî duyarlığı olan programları yutuyor. Bu tür programlar televizyonun doğasını muayyen zamanlarda dönüştürebilse de her şeyi eğlenceye dönüştüren televizyon ne çocuk ne de yetişkin ruhuna ayna olabiliyor.

\section{Çizgi Film Dini Anlatmaya Ehil midir?}

Çizgi sineması, "geniş seyirci kitlelerine" ulaşması ve "popüler duruma" gelmesi nedeni ile "din kurumlarının" da dikkatini çekmiş bir sanat dalı. Bu yaklaşım, dinin sinema ile anlatımını savunan görüşlere paralel bir anlayışı içermektedir. Batı dünyasında püritenlerin sinema ve çizgi filmi çocuğun eğitiminde önemli bir eğitim materyali kabul etmelerinden sonra, önceki yüzyılın ilk çeyreğinden itibaren dinî konularda çizgi filmin kullanıldığını biliyoruz.

Dinî söylemi çocukların anlayabileceği bir dil kullanarak, çocuğun zihin ve ruh dünyasına, hayal ve tasavvur âlemine girecek çizgi filmler aracılığıyla iletme düşüncesi ne kadar doğrudur? Öncelikle bu görüş, çizgi filmi olumlayan şu yaklaşıma dayandırılıyor: İnsanın beş duyusuna hitap eden basit, geçici gerçekçiliğin karşısında, onun ruh ve zihin dünyasını sarmalayan manevi ve kalıcı ahlaki değerlerin bir kaneviçe şeklinde 
işlendiği çizgi film üslubu/biçemi küçük seyircilerin algı gelişiminde çok müspet sonuçlar doğuracaktır. Bunun için önerilen yaklaşım özetle şöyle özetlenebilir: Çizgi filmi estetik ölçülerle kotarmak, imalı ve çağrışımlı bir anlatım dilini işlerliğe sokmak, zengin bir muhtevayı, aşkın bir üslûba dayalı bir biçimle aktarmak. Bu yaklaşımda görüldüğü gibi çizgi film dili kendi düzleminde kabul ediliyor ve dinî muhteva ayrımına gidilmiyor.

Bu noktadan itibaren ana sorumuzu sormamız gerekecek: Ontolojik oluşumu kutsal bilgi temeline dayanmayan bir türün dili ile dinî muhteva doğru yansıtılabilir mi? Çizgi filmin oluşumunda belirleyici olan görüntü hızı ve hareket, bu türün dramatik dilinin belirleyicisidir. Çizgi filmin hıza dayalı dramatik dili ise dinî kozmosun dürbünü ile bakmaya engeldir. Varlık nedeni dinî kozmosa müdahale olan çizgi sineması dili, dinin doğasını yansıtabilir mi? Çizgi sinemasına din dili'nin yani kutsalın dili'nin egemen olması ve manevî aşkınlığa dönüşmesi kaydı ile, Evet, diyebiliriz. Aksi takdirde dinin sahihliği, doğası ve gerçeği, sanallaşma tehlikesi ile karşı karşıya kalması söz konusudur. Muhtevanın kendi bağlamından uzaklaşarak sanallaşması çizgi filmin algı oluşumu ve çizgi mantığı nedeniyledir. Burada bir ara soru sormamız gerekecek: Çizgi film mantığını oluşturan algılama boyutunun belirleyicileri nelerdir? Kuşkusuz, hipereğlence hız ve haz. Çizgi film mantığını çocukların ve yetişkinlerin farklı algıladıklarını gelişim psikolojisi araştırmalarından biliyoruz. Örneğin, dört yaşındaki çocuklar çizgi film kahramanlarının gerçek olmadığını kavrayamadıkları gibi onlarla özdeşleşebilmeleri de kolaydır. Yedi yaşında ise kahramanların hayal ürünü olduklarını da bilirler. Ancak, bu yaştaki çocuklar, çizgi filmin hayalin sündürülmüş iskeleti olduğunu bilmezler. $\mathrm{Bu}$ ise çizgi filmlerin çocuk zihnini hayale kapatan etkisi olarak açıklanabilir.

Yeni çocukluğun deve gücü tazı hızı şurubu kabul edilen çizgi sinemasına, yalnızca dinî muhtevayı doğru yansıtmadığı noktasından hareketle eleştiri getiriyor değiliz. En azından dinî muhtevanın dönüşme ihtimalinin daha yüksek olduğuna işaret etmiş oluyoruz. Çünkü çizgi filmler dramatik modern mit'lerdir. Soyut algı döneminde çocuklar, çizgi film kahramanlarının yapay olduklarını bildikleri gibi, kendilerine zarar vermeyeceklerine de inanırlar ve yine bu nedenle en korkunç çizgi film olaylarını izlemekten bile geri durmazlar. Çizgi filmden algıladıkları korku ve tehlikenin geçici olduğuna dair deneyimleri vardır. Kahraman silindir

Çocuk ve Medeniyet 2021/2 altında kalsa da ölmeyeceğinden emindirler. Pedagoji geleneğinin çizgi filmlerin ilk amacının "öğreticilik” olduğuna çekinceli yaklaşmalarının nedeni de budur. 
Benim çekincemin gerekçesi ise çizgi filmin varoluş biçiminin gerçeklikle bağdaşmayan görüntü illüzyonu ve hilesine dayanmasından dolayıdır. Çekincemin dayanağı ise, çizgi filmlerin çocukların muhayyilesini beslemediği tezine dayanmaktadır. Çizgi filmlerin hayal yeteneğini öldürdüğü ise 1960'tan bu yana çocuklar üzerinde yapılan yüzlerce araştırmanın sonuçları arasındadır. Hayalin ölümü ise çocukla metafizik dünya arasındaki iletişim kopukluğu anlamına gelir.

Temel yaklaşım olarak, popüler bir sanat dalı olan çizgi filmin çekincesiz olumlanması ve dinî muhtevaya uygun bir tür olduğunun kabul edilmesi çizgi filmin doğası ile de çelişmektedir. Bu yaklaşım, çizgi film dili'nin dinî muhtevaya uygun olduğunu da kabul anlamına geliyor. Çizgi filmin dinî söylemin anlatımına uygun olduğu görüşünü savunanlara karşı görüşlerimi de özetle açıklamak istiyorum: Çizgi filmin hazcı ve eğlence mantığına dayalı dili ile dinî muhtevanın dinin doğasına uygun içeriğin anlatımı mümkün değildir. Çizgi filmin dramatik dili dinî kozmosun dürbünü ile bakmaya engeldir. Bu tutumun sürdürülmesi durumunda çizgi filmin görüntü illüzyonundan oluşan dinî içeriği dönüştürmesi kaçınılmaz bir sonuçtur.

Ana sorumuzu burada tekrar sorabiliriz: Ontolojik oluşumunu kutsallığın belirlemediği bir türün dili ile dinî muhteva doğru yansıtılabilir mi? Varlık nedeni dinî muhtevanın -vahyin- iletisine müdahale olan çizgi sineması dilinin, dinin doğasına müdahale ettiği hipotezime/denence dayanan görüşüm özetle şudur: Çizgi sinemasına din dili’nin yani kutsalın dili’nin egemen olması kaydı ile ancak -dinî temalı öyküler- çizgi filmle anlatılabilir. Aksi takdirde sanal bir dinî muhteva oluşturmaya katkıda bulunmuş oluruz.

\section{Medyanın Kör Noktası: Din}

Dinin yetişkinlere ait inanma biçimi ve kutsal bir alan olarak sunulması bugüne ait bir yaklaşım değildir. Dinler tarihi boyunca din açısından çocuk, özne durumuna gelememiştir. Bunun sonucu olarak çocuk, yetişkinler için oluşturulan gelenek içinde dinin dünyasını kavramak zorunda kalmıştır. İnanma insanın doğasının gereğidir. Din, çocuğu da içine alır. Çocuğun inanmaya uygun ruhî yapısı modern seküler psikoloji ile daha girift bir duruma gelmiş bulunuyor.

Çocuğun ruhen inanmaya elverişli ve yatkın oluşu ve ruhî yapısından

Çocuk ve Medeniyet 2021/2 kaynaklanan tecessüsü, onu, din alanı ile kuşatır. İnanma içseldir. İçinde olmayan bir düşünce ve duyguyu insanın içine yerleştirmek ise imkânsızdır. Çocuğun kolayca inanma ve bağlanması yine ona ait ruhî özelliktir. 
Çocuk ruhunun derinliklerine inildikçe, çocuk, ruhî yeteneklerini harekete geçirir.

Çocuk ruhu hem inanmaya açı hem de isteklidir.

Çocuk, inanmak için arayışa girer ve soru sorar. Sorduğu sorulara aldığı cevaplarla ve önce taklitle maneviyat kozasını örmeye çalışır.

Yetişkinlere düşen görev çocuğun dine ilişkin sorularını anlamak ve dinin anlamını kavramasına yardımcı olmaktır.

Çocuk, dinî dünyasını kurmaya çalışırken, yetişkinler ona olumlu yönde etki edebileceği gibi olumsuz yönde de etki edebilirler. Daha açık ifade ile yetişkinler çocuğa dinini öğretebileceği gibi, din duygusunu köreltebilirler.

Yetişkine düşen ilk görev çocuğun Allah hakkında sorularına cevap aramaktır.

İnanma isteği doğuştan var olan ruhî yaratılışın nimetleri ile donandıkça olgunlaşabilir. Çünkü din, önce ruha aittir ve ruha seslenir.

Çocuk ruhunda güçlü bir şekilde Allah'a giden bir yol bulunduğu, gelişim psikolojisinin de tespit ettiği varoluş gerçeğidir. Ve psikoloji, dinî inancı, çocuk ruhunu sınır tanımayan arayışa bağlar. Arayışın temelinde ise kendini güven içinde hissetme isteği vardır. Çocuk, sorduğu sorulara istediği karşılığı aldıkça kendisini güven içinde hissedecek ve inanç kozasını örmeyi sürdürecektir. Bu ihtiyacı karşılanmadığı takdirde ise metafizik dünyayla ilişki kuramaz maneviyat kozasını öremez duruma gelir.

Çocuğun oluşturduğu dinî inanç, dinî dünyası ve düşüncesi yetişkininkinden farklıdır. Çocuğun ve yetişkinin dinî farklı algılaması da bir yaratılış gerçeğidir.

Çocuğun içinde geliştirdiği din, ruhî yapısına uygun ve çocuğa özgü bir "çocuk dinî"dir. Ruhî güçleri ve yeteneklerinin harekete geçmesi ile oluşan bu "çocuk dini", çocuğun gelecekteki din anlayışının ilk kozasını teşkil eder.

Modern çocuk paradigmasına dayalı çocuk modernleşmesi seküler bir temele dayanıyor. Bu paradigmanın içinde çocuk ve din ilişkisi ise en zayıf alandır. İletişim araçları din'e karşı kör olduğu gibi, özellikle çocuk programlarında en yasak bölge yine din'dir. Çocukların küresel ve seküler kuşatma altında olduklarını söylemek kolaydır. Bu aynı zamanda bir tür kaçıştır. Bu kaçış aynı zamanda çocuğun en temel hakkı olan inanma hakkının farkında olamamak demektir. Bunun sorumlusu ise iletişim araçları değil biz yetişkinleriz. 


\section{Modern Çocukluk ve Sanal Din}

Çocukluğun anlamını bilen bin yıl yaşamış gibi olur. Tam olarak bunu bilmek ise imkânsızdır. Çocukluğun anlamını bilme çabası olmadan hayatın anlamını fark etmek de mümkün olamaz.

Çocuk da kendi anlamını bilmez. Çocuk, hayata dair tecrübesi olmayan varlıktır. Tıpkı bir filozofa benzer çocuk. Hayret etme yeteneği çok güçlüdür. Tereddütsüzdür; hayata şaşarak bakar. En yaman sorularını sormaktan da çekinmez. İlk çocukluk evresinde sorduğu en çetin soruları ise çocuk maneviyatı ile ilgilidir. Çocuğun kendini gerçekleştirme süreci ne kadar erken başlarsa hayatın farkına varması da o ölçüde kolaylaşır.

Kimdir çocuk? Çocuk insandır. Çocukluk ise insan hayatının kök saldığı evredir. Çocuğun çocuk olduğu görüş birliği hâlinde kabul edilir; ancak çocuğun anlamı hakkında tıpkı hayat konusunda olduğu gibi görüş birliği yoktur.

Hayat nedir? İnsanın yaşama serüveni. İnsan hayata dair ödevlerini yerine getirerek iyi yaşayabilir. Nedir iyi? Hakikiliktir; insanın ayakta kalması için yardımcı kuvvettir. Fernando Savater, iyi yaşamak için haklı bir duygudaşlık adaleti ya da haklı bir acıma duygusuna sahip olma yeteneğinin gerektiğini hatırlatır bize. Tagore, en iyi, arkadaşlarla birlikte gelir, diyor. Yaşadığımız çağda ise iyi konusunda da insanlığın kafası bir hayli karışık. İnsanlığın görüş birliği içinde olmadığı konulardan biri de ne yazık ki nelerin "ortak iyi" olduğudur.

Bana göre en zor iki soru, “Çocuk Nedir?” ve "Hayat Nedir?” sorularıdır. Niçin zordur bu iki soru? İnsanoğlu henüz hayat ve çocuk hakkında görüş birliğine varamamıştır. Buna karşılık, çocuk ve hayat konusunda hemen herkesin konuşması ise anlaşılır bir şeydir. Çünkü her ikisi de birbirini var eden gerçekliğin özüdür.

İnsanoğlunun çocuk ve hayat konusunu daha anlaşılır hâle getirmek için çağlar boyu teorilere ihtiyaç duymasının nedeni de bu olmalı. Çocukluğun ne olduğunu anlamaya çalışan en basit teorinin "çocuk/küçük insan teorisi" olduğu kabul edilir. Çocuk gelişiminin yalnızca büyüme süreci olduğu noktasını merkeze aldığımızda makul bir teoridir bu. Bu noktadan itibaren, Gareth B. Matthews'ın, "Çocuğu tanımak için iyi bir çocuk teorisine ihtiyacımız var mı?” sorusunu ödünç alarak ilerleyelim:

Çocuk ve Medeniyet 2021/2
Gareth B. Matthews, çocukluk üzerine teoriler kurabilecek ilk kişilerin psikologların olması gerektiği görüşünde (Matthews, 2000, s. 31-15). Ama, diyor, eğitimcilerin de belli başlı teorileri olması gerekir; tıpkı antropologlar, 
dilbilimciler, kültür tarihçileri ya da siyaset bilimcilerin teorilerinin olması gerektiği gibi. Çocukluk kavramı felsefi anlamda sorunlu olduğu için listede felsefeciler olmadığı gibi modern çocuk bilimi çevrelerinin geleneğine uygun olarak teologlar da yok. Niçin yok? Batı aydınlanması, temelinde geliştirilen eğitim teorilerinin dini kiliseye bıraktığı için yok. Rönesans sonrası dinin sürgün edilmesi gerektiği için yok. Din kiliseye bırakıldığı ve okulun din iklimine uzak tutulması öngörüldügü için yok.

Hiçbir çocukluk teorisinin diğerine üstünlüğü olmasa da deneyime, yinelemeye ve yaradılış̧̧ı modellere dayalı teorilerin daha sık kullanıldığını biliyoruz (Matthews, 2000, s. 28-39). Benjamin Spok'un “İnsanoğlunun tüm tarihini yinelemektedir çocuk." yaklaşımını esas alan yineleme teorisi, bireyin gelişim süreci boyunca insanlığın gelişim sürecini tekrarladığı esasına dayanır ve sözünü ettiğimiz modeller arasında en popüler olanıdır. Buna karşılık hiçbir modern çocukluk teorisi medeniyete vurgu yapmaz.

Kuşkusuz, insanın/çocuğun en anlamlı ve kuşatıcı bilgi kileri ve pedagojik tecrübe medeniyet'te vardır. Her medeniyet, çocuk dili, çocuk bakışı ve çocuk yetiştirme geleneğine dayanarak çocukluk kozasını örer. Bizi çocuk anlayışı ile yüzleştiren en temel belirleyici medeniyetin pedagojisidir. Medeniyetlerin çocuk konusunda birleştiği ortak nokta, "en iyinin” önce çocuklara ait olduğu yaklaşımıdır. Semavi dinlerin ortak çocuk anlayışı ise çocuğun “Allah'ın emaneti” kabul edilmesidir; çocuk ve dünya, yetişkinlere emanettir.

Medeniyetimizin dayandığı çocuk anlayışının temeli ahlak eğitimidir. Çocuk yetiştirmek, pratik ahlakın ana meselesidir. Çocuğun irade, ahlak, vicdan ve adalet duygusu eğitiminin kozasının özüi ise çocuk maneviyatıdır. Çocuk maneviyatı, çocuğun yaradılış doğasına ve ilahi mimarisine uygun eğitilmesinin funda toprağıdır.

Aslında çocuğu konuşmak bir çocukta bütün çocukları, dahası, bütün insanlığı konuşabilmektir. Semavi dinlerin hareket noktası, Hz. Adem'i insanlığın başlangıcı kabul etme esasına dayanır. Çocuk ise insanlığın geleceğe dönük yüzüdür. Bu nedenle çocuk, en büyük insanlık gerçeği ve en anlamlı Evet'tir. Çocuk üzerine konuşmanın ikinci anlamı ise çocuğun bütün insanlığın serüvenini konuşmaya yönelik temel özne ve başlangıç olmasıdır.

Yenidünyada çocuk, doğasını yansıtmayan, temelsiz, eksik ve bilinçsiz çalışmalardan olduğu kadar başka hiçbir şeyden bu kadar sarsıcı zarar görmemiştir.

144

Çocuk ve Medeniyet 2021/2
Modern çocuk tasarımı Rönesans'ın en pedagojik ütopyasıydı. Bugün, çocukları tanımada kullandığımız dil ise 19. yüzyıldan bu yana gelişen modern ve seküler çocuk dili'dir. 
Sosyal tarihçi Philippe Ariés, çocukluğun icat edildiğini savunuyordu. Çocuk gelişimini inceleyen psiko-tarihçi Erikson ise çocukluğun kültürel bir oluşum sonucu ortaya çıtığını ve geliştiğini ileri sürmüştü. Aslında, modern çocukluk tasarımı, icat edilen yapay bir kurgudur. Rönesans'ın en insanî tasarımı olarak alkışlanan bu tasarım, aynı zamanda 19. ve 20 . yüzyılı etkileyen iki entelektüel çocuk anlayışı olarak belirir: Locke'un öncülüigündeki Protestan anlayışta çocuk, "biçimlenmemiş bir kişi”dir. Rousseau'nun öncülüğünü yaptığı romantik çocuk anlayışında ise, çocuk, “bozuk biçimli yetişkin”dir. Gerek Locke'cu gerekse Rousseau'cu çocuk yorumlarında çocuk ve yetişkinin farklı olduğu hipotezi öngörülse de çocuk ve yetişkin teorileri birbirini tamamlamaktan çok, birbirine dönüşmüş psikolojik kurgulardır.

Çocukluğun kültürel bir oluşumla var olduğunu savunduğu ve paracı felsefe anlayışına dayandığı için modern çocukluk anlayışına itiraz edenlerden biri de Neil Postman'dır. Postman, modern çocuk kurgularının oluşturduğu yapay çocukluk yerine, çocukluğu dil öğrenimine benzetir. Çocukluğun biyolojik temeli vardır; fakat sosyal bir çevre çocukluğu başlatmadıkça ve bakıp büyütmedikçe yani ona ihtiyaç duymadıkça gerçekleşmeyebilir.

Neil Postman, tek bir çocuk yorumu olmadığını hatırlatarak modern çocukluk ve yetişkinliğin açmazını da fark etmemize yardımcı olur: Hiç kimse çocukların yetişkinliği başarabilmesi gerektiğini tartışmamıştır. Hiç kimse çocukların yetişmesiyle ilgili sorumluluğun yetişkinlere ait olduğuna itiraz etmemiştir. Gerçekte hiç kimse, çocukların bakımı konusunda yetişkinlerin en iyi ve en uygar olduklarına ilişkin anlayışı tam anlamıyla tartışmamıştır. Modern çocukluk paradigmasının modern yetişkinlik paradigması da olduğunu hatırlamalıyız. Çocuğun ne olmasını istediğimizi söylediğimizde, kendimizin de ne olduğunu söyleriz... (Postman, 1995, s. 95-153-192).

Modern çocukluk tasarımı anlayışı, yeni çocukluğun biçimlenmesinde en etkili süreç olmayı sürdürüyor. Din ise bu çocukluğun seküler bahçesinden kovulmuştur. Sanal cennetlere ve paracı ütopyalara alıştırılan dünya çocukları için din, sanal bir algı düzeyine indirgenmiştir. Rönesans'ın kiliseye ve vicdanlara terk ettiği din ile çocuğun ilişkisi ebeveynin dindarlığı ile sınırlı kalmıştır. Bu nedenle çocuk maneviyatı, eğitimin merkez üssü olan okulda ya bir kültür dersidir ya da din bilgisi düzeyindedir.

Tarih boyunca çocukla din'in arası hiç bu kadar açılmamıştı. Ve insanlık hiçbir çağda din'e karşı bu kadar kayıtsız kalmamıştı. Bu ise, insanlığın yeniden çocuğa ve din'e dönüşün eşiğinde olduğu anlamına mı gelmektedir? 2021/2 


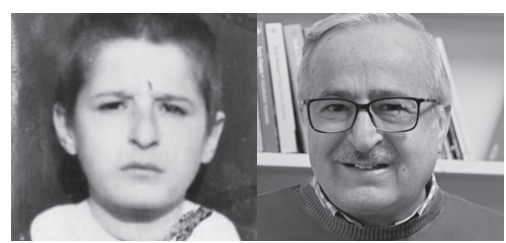

Mustafa Ruhi Șirin

\section{Kaynakça}

Batmaz, V., Aksoy, A. (1995). Türkiye'de Televizyon ve Çocuk. Ankara: Aile Araștırma Kurumu Yayınları. Debord, G. (1996). Gösteri Toplumu ve Yorumlar (Cev.: A. Ekmekçi, O. Tașkent). İstanbul: Ayrıntı Yayınları.

Doḡan, D. M. (1996) “Aile, Kadın, Cocuk ve Medya”. Yeni Türkiye Dergisi, Kasım-Aralık 1996, Sayı 12

Matthews, Gareth B. (2000). Cocukluk Felsefesi (çev.: E. Çakmak). İstanbul: Gendaș Yayınları.

Postman, N. (1995). Çocukluḡun Yokolușu (çev.: K. İnal). İstanbul: İmge Kitabevi.

Postman, N. (1994). Televizyon: Öldüren Eğlence (çev.: O Akınhay). İstanbul: Ayrıntı Yayınları.

Șirin, M. R. ( 1999 ). Kușatılmı Çocukluḡun Öyküsü. İstanbul: İz Yayıncılık.

Tapper, R. ( 1993 ). Çaḡdaș Türkiye'de İslam-Din, Siyaset, Edebiyat ve Laik Devlet (çev. Ö. Arıkan). İstanbul: Sarmal Yayınları. 